\title{
Apartheid in Former Racial South Africa
}

\author{
Rodrigue Ntsatou*, Basile Marius Ngassaki \\ Université Marien Ngouabi Faculté des Lettres, Arts et Sciences Humaines
}

*Corresponding Authors: Rodrigue Ntsatou, Université Marien Ngouabi Faculté des Lettres, Arts et Sciences Humaines, Congo

\begin{abstract}
This article deals with the issue of apartheid in South Africa. Our goal is to show how the Natives resisted against the white man's penetration who finally established the apartheid regime. Despite the natives' resistance, they were dominated by white men, not only motivated by political reasons but also economic and social ones. So, from1948until 1994, the whole political and economic power in South Africa was totally in the hands of the whites. Through socio historical approach, we have noticed that the white minority objectified the Black majority through some strategies.
\end{abstract}

Keywords: Apartheid, Former, Racial, South, Africa.

\section{INTRODUCTION}

Being part of the world, Africa is actually constituted of 54 countries including South Sudan, classified into different geographical zones: Central Africa constituted of seven countries; West Africa made up of sixteen countries; East Africa composed of nine countries; Austral Africa with its nine countries; finally, North Africa with five countries. So, all these countries integrate the map of Africa. But the African history is at some moments due to some phenomena such as: land occupation, boundaries, ethnic tensions, colonization, slavery, etc. And these issues have led to significant changes in Africa in general and in South Africa in particular.

However, the present study is to situate readers to the main purpose when reading African civilization in general, and the history of former racial Apartheid in SouthAfricafrom 1948 to 1994in particular. The Natives' struggle against Apartheid is the main concern of our work. It is in this sense that our study is entitled: Apartheid in Former Racial South Africa. As we can see, the current topic raises an interesting question that we hope to scrutinize in this study. How did the Natives resist against the white man's penetration?

Concerning the review of literature, we have to mention that there are different works related to the history of Apartheid. Many writers have already worked on this topic. The available academic studies are mostly related to the study of Africa in the sense of history, sociology, or civilization. Indeed, this study is going to be made clear in relation with Bill Freud in The Making of Contemporary South Africa, Indiana University, Bloomington, 1984, p.5, when he started the following:

Every self-conscious nation looks back upon its past to revive former glories, to discover its origins, to relate its history to that of other parts of the world and to arrive at a knowledge of the development of its political, social, economic and other system.

This quotation sounds right if we contextualize the situation in all societies in Africa in general and in South Africa in particular. Even African old societies also were not out of this reality.

About methodology, we shall use the socio-historical approach in the fact that the problems of Africa have a long history that requires looking at contemporary developments in Africa through the study of past events. Our study will start by examining the Natives' Resistance against the White man's penetration. Next, we are going to see the Anglo-Boer War (1899-1902) and the Creation of the "Union."Then, Apartheid and its main manifestations will constitute the third step of our work.

In this section, we shall write about the origin and the definition of the concept of apartheid, including the Basic Laws which enforced apartheid and its main architects. Furthermore, the natives' struggle against apartheid will be seen as the fourth and the last part of our work. 


\section{The Natives' Resistance Against The White Man's Penetration}

Concerning the Natives' opposition against the White man's penetration in South Africa known as "The Kaffir Wars", we have first of all to mention that the dispossession by the Boers of the aborigine populations from their lands did not go without any resistance or opposition from them, a resistance that during many wars was commonly known under the term of "Kaffir Wars".

The most famous Zulu King who fought fiercely against the white man's occupation of the natives' lands was King Shaka. Born in 1795, King SHAKA was the son of Princess Nmandi and King Senzangakhona.

The one who succeeded Shaka known as King Dingane and the Zulu were extremely defeated on December 16, 1838, while struggling against the Voortrekkers, that is to say, those who participated in the Trekk, still remembered under the name of the "Blood River Battle."

Other most famous African kings who resisted the White man's illegal penetration of their lands were:

- King DingInswaho of the Mthethwa

- King Moshoeshoeof Basutho

-King Sobhuza of Swazi, and

-King Zwidf of the Ndwandwe to name but a few.

\section{The Anglo-Boer War (1899-1902) And The Creation Of The "Union"}

Dealing with the Anglo -Boer war (1899-1902) and the Creation of the "UNION", this war was a result of the enmity between the British in their goal to build a whole British South Africa and the Boers or the Natives.

In the first time, it opposed Cecil Rhodes (to whom former Rhodesia, or present day Zimbabwe) owed its name on the one hand, and Paul Krugger on the other, and later on Field Marshal Robert and General Kitchener against Generals Botha, de wet, Hertzog and Smuts.

It stopped on May 31, 1902, with the signature of the "Treaty of Vereeniging" in which the Boers approved the peace terms offered by the British military chief, Lord Kitchener. These stipulated among others that they were to lay down their arms and to recognize themselves as subjects of King Edward VII of England, and the English Language was to be used in schools and law courts while in 1925, by an Act of Parliament, the Afrikaans would become the second official language in the place of High Dutch.

By the year 1910, the "Union" i.e. the making of South Africa with its former independent government in which there were no Africans was established.

\section{APARTHEID AND ITS MAIN MANifESTATIONS}

In this section, entitled apartheid and its manifestations, we are going first to present the origin or the historical process of apartheid including its meaning. Then, we shall find out basic laws that enforced apartheid as well as its main architects.

\section{a / Origin and Definition of the concept of Apartheid}

As said above, to speak of apartheid and its main manifestations, it is not unnecessary to start with the origin of the concept of Apartheid and then, to come to its definition.

As we have just seen it in the forgoing part, apartheid took its roots far back in history, almost as soon as the White man discovered Africa and started to conquer it, dispossessing the native populations from their lands and securing the most fertile lands for themselves and for their own interests, thus, turning the former independent African farmers and cattle breeders into workers on their own existensive farms.

Thus, at the very beginning of the history of South Africa, the patterns that a few years ago still governed it were already established: a complete domination of the Black by the White who had become his master and he, his servant. 
To make it clear, apartheid as an official government policy, to be enforced firmly through the whole of the country, was first of all adopted by the year 1948 when the Afrikaan Nationalist Party won the elections and under Dr. Daniel Malan, became the government of South Africa.

And racial segregation being the main point in their platform, it was unavoidable that during the Nationalist rule the important laws enacted by Parliament and executed by the government had to do with race, as a manner of favouring white dominating influence and also of enforcing racial discrimination.

Indeed, Apartheid was a political, socio-economic system focused on the basis of separate development for every race in South Africa. It aimed at establishing a white nation on the continent.

\section{b/ Basic laws that enforced apartheid and its main architects}

The following are the main laws that enforced apartheid and its main architects.

once after the "Union" was created, one of the most important laws that was ever enacted by Parliament was the "Colour Bar" (1911). The "Colour Bar", qualified manpower in the mines in particular was reserved to Whites only.

"The Land Act" (1913) forbade all Africans to possess lands of their own, except in different zones reserved to them. And these zones reserved to them were located in the mountains.A major step towards apartheid with the Nationalist rule was the classification of the population according to their racial origins.

"The Population Registration Act" (1950) compelled the people to register and provided all information necessary to identify whether they belonged to the "White", "Bantu" or "Coloured" group. A population Register was created and identity cards were distributed to the populations.

"A Prohibition of mixed Marriages Act" (1949) made marriages between Whites and non -Whites illegal and declared not legally valid mixed marriages involved abroad.

"The Immorality Amendment Act" (1950) prohibited sexual relations between Whites and nonWhites.

"The Native Building Workers Act" (1951) prevented the employment of Africans on skilled building work in white areas and provided short training courses for Africans to enable them to build houses in African areas.

"The Group Act" (1950) was the most far reaching of all apartheid legislation in the first five years of the NationalParty Government: it set up machinery for the effective segregation of all races by removing and the resettlement, the expropriation of property and the proclamation of reserved racial areas or zones.

"The Bantu Authority Act" (1951) provided the basis for the return to tribalism and the installation of government -supported chiefs.

"The Natives Abolition of Passes and Coordination Document" (1952) made it essential for all Africans, women and men, over the age of sixteen, to carry reference documents containing detailed information regarding themselves, to be presented on demand by the police or other designated officers.

About the main architects of Apartheid, we have to mention that, apart from Malan, other architects of apartheid were:

Strijddom who succeeded Malan and launched the "baaskap," another kind of white power in which the White must be the "baas", that is to say the master.

Werwoerd under whom apartheid was fully established South Africa with his country's withdrawal from the Commonwealth (March 1961) and its became a Republic in April 1961. He was the one who privileged the creation of black reserves or Bantustans as a solution to their demands.

Dr. J. Voster who succeeded Werwoerd after he was assassinated (by a white man) in 1966.After them, came Ian Smith, Peter Botha and Frederick de Klerk under whom apartheid was outlawed or abolished, in June 17,1991 presently, considered as the date when apartheid was abolished including the liberation from jail of Nelson Mandela. 


\section{The Natives' Struggle Against Apartheid}

Concerning the Natives' Struggle against Apartheid in South Africa, we have to say that the million vote less of non-white communities were not unmoved by the succession of laws enacted by Parliament to enforce or impose racial discrimination against them.

Indeed, in reaction against the police sudden attacks for passes and the illegal possession of liquor, against inadequate housing and transport, the rising cost of living, low wages and other difficulties, non-white organisations became very active, leading to public demonstrations and to the process of mass protests.

The African National Congress (ANC), under the leadership of its former - Chief Albert Luthuli, had by this time become the mass movement of the African people. Formed in 1912 by conservative Africans educated abroad, (Prof. Moraka and Reverend Father John K. DUBE), in conjunction with tribal chiefs, as a means for the participation of Blacks to power, a non-violent movement against racial discrimination, the ANC had pursued a course of passive protest until the 1940's when a militant younger generation asserted itself. In 1943, the Organisation declared that its target was:

to attain freedom of the African people from all discriminatory laws whatsoever. (xxx)

And in 1945, it published a Bill of Rights demanding full citizenship rights. This was followed by a programme of Action calling for an end to co-operation with governmental institutions and for boycotts, strikes and civil disobedience. In December 1951, the ANC wrote to the Parliament asking for direct representation in the Voters 'Act, and an end to remove people considered as inferior persons in reserves.

As a rule, each new parliamentary measure to extend and impose apartheid was met with new protests, conducted by the ANC, which persistently called for an end to discrimination and for cooperation between Blacks and Whites in order to find a pacific solution toracial problems in the country.

In its struggle against racial discrimination, the ANC was supported by the South African Indian Congress, the South African Coloured Peoples' Organisation and the South African Congress of Democrats (COD). The last named was an organisation of white South Africans, among them some former members of the banned Communist Party. Its policy was 'to secure for all South Africans, in spite of race colour or creed, the rights laid down in the Universal Declaration of Human Rights' and to oppose all forms of racial discrimination.

The Congress of the people which took place inKliptown, near Johannesburg, on June 26-27,1955, was attended by more than 3,000 delegates of all races, and was gathered by the ANC and the other three organisations mentioned above, including the South African Trade-Union Congress. It aimed at adopting a 'Freedom Charter' focused largely on the United Nations Universal Declaration of Human Rights.

The forceful requests of non-Whites were thus set out under 10 (ten) printing titles. The most important of which are:

-The people shall govern

-All national groups shall have equal rights

-The people shall share the country's wealth

-The land shall be shared among those who work it

-All shall be equal before the law

-All shall enjoy equal human rights

-There shall be houses, security and comfort

-There shall be peace and friendship ...

By December 1958, the difficulty or suffering caused by the stricter administration of harsh racial law, made more unbearable by general poverty and rising living costs, urged the African National Congress to prepare for a long and bitter struggle against the pass law. A march of deputations to local 
authorities and Bantu Affairs Commissioners throughout the country, on March 31,1960, urging for the abolition of passes was decided, to be followed on April 15 to be considered as "African Freedom Day" by many mass meetings.

A group of people who disagreed, under the leadership of Robert Sobukwe, calling themselves Africanists, refused the African National Congress' policy of multi -racialism and demanded 'Africa for the Africans'. They created a new organisation called the Pan -African Congress (PAC).

The Pan-African Congress preceded the African National Congress by choosing March 21 instead of March 31 as the day on which to present themselves at police stations without passes. On that day, large crowds of Africans assembled to join in the PAC demonstration.

In most places, they were dispersed by the police but at Sharpeville, in the Transvaal, the police opened fire on the crowds, killing 69 and wounding 178. (Soweto Massacre took place on June 16, 1976, nowadays commemorated as the African child International Day. On that day, more than 600 students were killed as they protested against the introduction of the 'Afrikaans' as the language by which they would be taught at school.)

Following the massacre of Sharpeville (March 21, 1960), many Africans round 20,000 people, among whom Nelson Mandela who was then the leader of the ANC after the former Chief Albert Luthuli and Robert SOBUKWE, leader of the PAC, were arrested and charged with incitement or for agitating against the pass law.

In a speech at his trial in November 1962, Nelson Mandela asserted the following:

'Government violence can do only one thing and that is to bread counter -violence [...] if there is no dawning of sanity on the part of the government, the dispute between the government and my people will finish up by being settled in violence and by force...

The ANC and the PAC were officially declared non authorized organisations by Proclamation $\mathrm{N}^{\mathrm{o}} 119$ published on April 8, 1960.

Following upon the banning of the ANC and the PAC in April 1960, and of the Congress of Democrats in September 1962, the burden or duty of extra-parliamentary political struggle fell again increasingly upon underground organisations. As early as December 1961, asubsidiary of the ANC, called Umkonto We Sizwe' Spear of Nation began to engage in illegal activity and to commit acts of sabotage.

At the same time, a new organisation which joined the PAC appeared in Cape Town under the name of Poqo (pure i.e. purely for Africans). Both these new organisations were declared as unlawful organisations in proclamations publicly announced on May 10, 1963.

By the middle of 1963, only dispersedsmall surviving groups of peoplefrom thePoqoorganisation remained since most of its members, 3,246 Poqo members had already been arrested.

In July 1963, the police succeeded in uncovering the secret headquarter of the ANC and Umkonto We Sizwe at Riviona, outside Johannesburg, where key leaders of both organisations, such as Nelson Mandela and Walter Sisulu, were surprised and arrested.

They were both all together with six (06) other leaders, among whom Govan Mbeki, (father of Tambo Mbeki who succeded Nelson Mandela as President of South Africa). Steve Biko(who championed 'Black Consciousness') and Poet Benjamin Moloise, and werejudged in June 1964 to life imprisonment. This would mean that, when Nelson Mandela was released from Robben Island jail in February 1990, he had stayed in jail for almost 27 years (1963-1990).

Other leaders such as Oliver Tambo, former Secretary - General of the ANC, Duma Nokwe and Moses Kotana, were obligedto run away from the country.

Arising from the arrests at Riviona in July 1963, the government of the Nationalist Party under the reign of Werwoerd was then able to oppress every remaining element of the non-white political movement. By June 1965, its leaders were either in jail serving long term imprisonments or were confined by banning orders or house arrest, or had fled beyond the borders of the country. 
In August 1983, a new organisation known as the United Democratic Front (UDF) was created. They organized and generalized insurrection in townships, which led to the proclamation of a State of Emergency under the regime of Peter W. Botha.

In spite of that, because of the international pressure, Peter Botha would start to purifyapartheid: "The Immorality Amendment Act" and 'the Natives' Abolition of passes and Coordinating Documents were abolished.

In October 1989, the Wall of Berlin which divided the world into two main blocks, the Communist block on the one hand and the Capitalist block on the other, was dilapidated and fell down. With the breaking apart of the Wall of Berlin were also broken apart all former Communist or monopartist countries. And the people claimed for democracy everywhere.

The Summit of Boyles which was held in 1992 was the consecration of this request for democracy in the world. And this, combined with internal pressure and international sanctions against the racist regime of Pretoria, led Frederick de Klerk to authorize former banned political parties namely: the ANC, the South African Communist Party as well as the PAC to start with their activities. In February 1990, he would release Nelson Mandela all together with other African political leaders from jail.

Finally, in June 1991, apartheid was totally abolished and South Africa was proclaimed to be a nonracial country, a Rain Bow country, in which all citizens, Blacks and Whites including Coloured, were called to share equal political rights. And in 1994, the first multipartist elections were organized all over South Africa, which elections were won by Nelson Mandela. Accordingly, April 26, 1994 is commemorated as "South Africa Freedom Day".

In the meantime, due to their incessant efforts to put an end to the apartheid regime and to restore peace in South Africa, Frederick de Klerk and Nelson Mandela were awarded the Nobel Peace prize in 1993, thus, joining the list of both who had already been awarded the same Prize. Namely, Albert Luthuli (October 1961) and Archbishop Desmond Tutu (1984)

\section{CONCLUSION}

Finally, we can simply assert that the key point with the apartheid regime in South Africa was not only political but economic as well. The whole political and economic power in South Africa until 1994 was totally in the hands of the upper class, (white minority)who objectifiedthe lower class, (black majority). As declared by Alex Hepple in his book entitled "South Africa," Pall Mall Press, London, 1966, p.254:

The strong overtones of race discrimination tend to obscure the fact that the framework of South African society is essentially class discrimination, with the whites as masters and the non-whites, the servants.

The political party known as The National Party which was always considered as the solepolitical party in power acknowledged that this issue could not survive.

It also recognized that non-whites were also entitled to freedom as well as to democratic rights no less than whites. But it emphasized that these rights could not be shared by both, whites and non-whites in a common society because in such anissue, the white minority would be dominated by the non-white majority.

\section{REFERENCES}

[1] Bill, Freud. The Making of Contemporary South Africa. Indiana University, Bloomington, 1984, p.5

[2] Rolihlahla Dalibhunga, Nelson Manela, "An Ecological Study” Trafford 2006

[3] L'Apartheid: Les Africains Témoignent, Editions de l'Agence de press-Novosti Moscou -1987

[4] A.S. Homby, Oxford Advanced Leaner's Dictionary of Current English, $7^{\text {th }}$ ed London: Oxford University Press, 2005.

[5] The New International Webster's Comprehensive Dictionary of the English Language, Florida: Trident International Press, 2004.

[6] Oford Advanced Learners' Dictionary. International Student's $7^{\text {th }}$, Edition. Oxford: University Press, 2017.

[7] The Longman Modern English Dictionary, (2006--:228)

[8] Oxford Advanced Learner's Dictionary, Oxford: OUP, 1989. 
[9] Webster's New World Dictionary, Cleveland: Collins, 1979.

\section{AUTHORS' BIOGRAPHY}

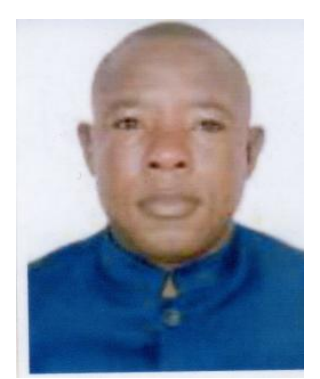

Rodrigue Ntsatou, is a doctor, and a permanent teacher at Marien Ngouabi University. The author of different articles and a doctoral thesis entitled:

"Conflicts Management in Africa From 1963 to the Present Day through the OAU and the AU." December 212019.

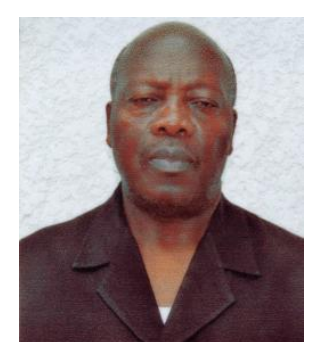

Basile Marius Ngassaki, is a Professor, the supervisor of the $\mathrm{PhD}$ training at Marien Ngouabi University, he is also the supervisor of numerous doctoral thesis, and the author of different academic works.

Presently, he is also working as the director of international conferences at the ministry of foreign affairs in Brazzaville. (Congo)

Citation: Rodrigue Ntsatou, Basile Marius Ngassaki. "Apartheid in Former Racial South Africa" International Journal on Studies in English Language and Literature (IJSELL), vol 9, no. 3, 2021, pp. 1-7. doi: https://doi.org/10.20431/2347-3134.0903001.

Copyright: (C) 2021 Authors. This is an open-access article distributed under the terms of the Creative Commons Attribution License, which permits unrestricted use, distribution, and reproduction in any medium, provided the original author and source are credited. 